\title{
Carvacrol and rosemary essential oil manifest cytotoxic, DNA-protective and pro-apoptotic effect having no effect on DNA repair
}

\author{
M. MELUSOVA ${ }^{1,2}$, D. SLAMENOVA ${ }^{2}$, K. KOZICS ${ }^{2}$, S. JANTOVA ${ }^{1}$, E. HORVATHOVA $2, *$ \\ ${ }^{1}$ Faculty of Chemical and Food Technology, Slovak University of Technology, 81237 Bratislava, Slovakia; ${ }^{2}$ Cancer Research Institute, Slovak \\ Academy of Sciences, 83391 Bratislava, Slovakia
}

${ }^{*}$ Correspondence: eva.horvathova@savba.sk

Received March 28, 2014 / Accepted June 30, 2014

\begin{abstract}
For several thousand years natural products were successfully used to treat a variety of diseases and to maintain health in humans, but until now it is not fully known what causes these medicinal effects. In our study we assessed the cytotoxic, DNA-protective and pro-apoptotic effect of two frequently occurring natural compounds, carvacrol and rosemary essential oil, on human hepatoma HepG2 cells. In addition we examined the in vitro incision repair activity of liver cell extracts prepared from hepatocytes isolated from Sprague-Dawley (SD) rats fed with water containing carvacrol or rosemary oil. Using conventional and modified single cell gel electrophoresis we proved that incubation of HepG2 cells with selected concentrations of carvacrol and rosemary oil significantly protected cellular DNA against two dangerous oxidative agents, hydrogen peroxide $\left(\mathrm{H}_{2} \mathrm{O}_{2}\right)$ and 2,3-dimethoxy-1,4-naphthoquinone (DMNQ). It is interesting that despite this DNA protection, the addition of both volatiles to the drinking water of SD rats had no effect on incision repair capacity of hepatocyte extracts. In this paper we also showed that carvacrol and rosemary oil can trigger apoptotic cell death pathways in HepG2 cells, which is probably connected with their cytotoxicity.
\end{abstract}

Key words: carvacrol, rosemary oil, cytotoxicity, comet assay, in vitro BER assay, apoptosis

Natural products and their derivatives play an important role in the development of current treatment guidelines. These products appear to be suitable chemoprotective agents against various types of cancer. Essential oils are formed as secondary metabolites by some kind of herbs. They are usually volatile, liquid, colourless and lipid soluble mixtures characterized by two or more major components. Essential oils have been widely applied for their antiseptic (bactericidal, fungicidal, virucidal) and medicinal properties. Generally, they manifested a cytotoxic (but not genotoxic) effect on living cells, depending on type and concentration [1].

Carvacrol is one of the major components of the essential oil of Thymus vulgaris or origanum [2]. It is well known for its antimicrobial, antitumor, antimutagenic, cell-protective, antioxidant, antiplatelet, analgesic, anti-inflammatory and antiangiogenic activities. Carvacrol is a monoterpene; it contains isopropyl and methyl groups in para position to each other on a phenol ring [3].

In general, Rosmarinus officinalis grows worldwide and extracts of different parts of this herb are used in folk as well as in modern medicine for their antioxidant and antibacterial activities [4]. The rosemary plant and its constituents are increasingly studied because of their positive effects on human health. Jiang et al. [5] showed pronounced activity of rosemary oil against Gram-positive and Gram-negative bacteria as well as fungi.

In our experiments we used $\mathrm{H}_{2} \mathrm{O}_{2}$ to induce mainly single-strand DNA (ssDNA) breaks and DMNQ to induce both ssDNA breaks and oxidative DNA damage. $\mathrm{H}_{2} \mathrm{O}_{2}$ is an oxidative compound which does not react with DNA directly. It induces DNA damage via highly reactive hydroxyl radicals which are generated from $\mathrm{H}_{2} \mathrm{O}_{2}$ in Fenton reaction catalyzed by metal ions, typically $\mathrm{Fe}^{2+}$ and subsequently react with DNA [6]. DMNQ belongs to the group of quinones, the toxicity of which is described by two principal mechanisms: i) the arylation of nucleophiles among biological constituents (e.g. covalent reaction with thiols), to form arylation products that are able to cause cellular damage [7]; ii) the oxidative stress caused by redox cycling as a result of one-electron reduction of quinones to semiquinone radicals which are then reoxidized 
by molecular oxygen and produce superoxide anions that are consequently converted into reactive oxygen species (ROS) [8]. It is known that base excision repair (BER) represents an important step in preventing mutations associated with 8-oxoguanine (8-oxoG) as a product of oxidative damage. Accordingly, the following mechanism for BER is supposed: damage-specific DNA glycosylases recognize and remove abnormal or damaged DNA bases to create an apurinic-apyrimidinic (AP) site in DNA. In the next step, other enzymes (AP endonucleases and phosphoribosyl lyases) are recruited to create proper ends for DNA polymerase which "installs" the appropriate nucleotide and DNA ligase finally joins the backbone $[9,10]$.

The aim of our study was to investigate the cytotoxic, DNAprotective and pro-apoptotic effect of carvacrol and rosemary essential oil on human hepatoma HepG2 cells. In addition we tried to ascertain if these natural compounds are able to influence BER, i.e. if the addition of these volatiles to the drinking water of Sprague-Dawley rats can stimulate the in vitro repair capacity of liver cell extracts.

\section{Materials and methods}

Plant volatiles. The plant volatiles examined in this study were: carvacrol (CA; Fluka, Buchs, Switzerland, purum $\geq 97 \%$; density $=0.974 \mathrm{~g} / \mathrm{ml} ; \mathrm{Mw}=150.22)$ and $R$. officinalis essential oil (RO; Calendula Inc., Nová Lubovňa, Slovakia, lot 5-014-009-12-06, containing approximately $25 \% 1,8-$ cineole, 19\% a-pinene, 19\% camphor, $17 \%$ p-cymene, $9 \%$ camphene, $5 \% \beta$-pinene, $2 \%$ borneol and $4 \%$ of unidentified components as specified by manufacturer). Both volatiles were kept at room temperature. Carvacrol was diluted to the concentrations 25-1000 $\mu \mathrm{M}$ in complete RPMI 1640 medium immediately before use. $\mathrm{RO}$ was dissolved in Cremophor $\mathrm{EL}^{\circ}$ (CrEL; Fluka, Sigma-Aldrich Co., Steinheim, Germany) and $70^{\circ} \mathrm{C}$ serum-free RPMI 1640 medium to $1.25 \%$ stock solution which was diluted to final concentrations $3.125-1250 \times 10^{-3} \%$ o in complete RPMI 1640 medium. The final concentrations of Cremophor EL in the medium never exceeded $0.1 \%$ (in both control and treated cells) which did not affect the cell viability.

Chemicals. Chemicals were purchased from the following sources:

2,3-Dimethoxy-1,4-naphthoquinone (DMNQ), 3-(4, 5-dimethylthiazol-2-yl)-2, 5-diphenyltetrazolium bromide (MTT), benzo[a]pyrene (B[a]P), bovine serum albumin (BSA), dimethyl sulfoxide (DMSO), ethidium bromide (EtBr), hydrogen peroxide $\left(\mathrm{H}_{2} \mathrm{O}_{2}\right)$, normal melting point (NMP) agarose, RNAse and Triton X-100 from Sigma, Sigma-Aldrich Co., Steinheim, Germany; fetal calf serum (FCS), kanamycin, low melting point (LMP) agarose, penicillin/streptomycin, Roswell Park Memorial Institute (RPMI) 1640 medium and trypan blue (0.4\%) from Invitrogen ${ }^{\mathrm{TM}} \mathrm{Gibco}^{\circledR}$ Life technologies Ltd., UK; formamidopyrimidine-DNA-glycosylase (Fpg) from BioLabs Inc., New England; phosphate-buffered saline (PBS; $\mathrm{Mg}^{2+}$ - and
$\mathrm{Ca}^{2+}$-free) from OXOID LIMITED, Basingstoke, UK; Ultra Safe Blue from Syngene, UK and proteinase K were obtained from the Biotech Company (Slovakia). Other chemicals were of analytical grade from commercial suppliers.

Cell culture. Human hepatoma HepG2 cell line was obtained from Prof. A.R. Collins (University of Oslo, Norway). Cells were cultured in RPMI 1640 medium supplemented with $10 \%$ fetal calf serum and antibiotics (penicillin $200 \mathrm{U} / \mathrm{ml} /$ streptomycin $100 \mu \mathrm{g} / \mathrm{ml}$, kanamycin $100 \mu \mathrm{g} / \mathrm{ml}$ ) on plastic Petri dishes at $37^{\circ} \mathrm{C}$ in a humidified atmosphere of $5 \% \mathrm{CO}_{2}$.

Treatment of cells. Exponentially growing HepG2 cells were treated with different concentrations of carvacrol or rosemary oil for $24 \mathrm{~h}$ on Petri dishes or 96 well-culture plates.

2,3-Dimethoxy-1,4-naphthoquinone (DMNQ) was stored as a $50 \mathrm{mM}$ stock solution at $-20^{\circ} \mathrm{C}$ and dissolved in serum free RPMI 1640 medium to final concentration of $50 \mu \mathrm{M}$. HepG2 cells were treated with DMNQ for thirty minutes at $37^{\circ} \mathrm{C}$ in the dark.

Hydrogen peroxide $\left(\mathrm{H}_{2} \mathrm{O}_{2} ; 10 \mathrm{M}\right)$ was kept at $4^{\circ} \mathrm{C}$ and diluted in PBS immediately before use to a final concentration of $300 \mu \mathrm{M}$. HepG2 cells embedded in agarose on microscopic slides were treated with $\mathrm{H}_{2} \mathrm{O}_{2}$ for 5 min on ice in the dark.

Cytotoxicity assay. The cytotoxic effect of both plant volatiles on HepG2 cells was evaluated by two different techniques - trypan blue exclusion (TBE) and MTT (3-(4, 5-dimethylthiazol-2-yl)-2, 5-diphenyltetrazolium bromide) assays. For TBE assay, cell culture was grown in monolayer on Petri dishes $\left(\varnothing 40 \mathrm{~mm}\right.$ ) from the density of $2.5 \times 10^{5}$ cells $/ \mathrm{ml}$ overnight and treated with either carvacrol $(25-1000 \mu \mathrm{M})$ or rosemary oil (3.125-1250 $\times 10^{-3} \%$ ) for $24 \mathrm{~h}$. After treatment, the cells were washed with PBS, harvested by $0.04 \%$ trypsin, resuspended in PBS, stained by $0.4 \%$ trypan blue and then the number of viable and dead cells was counted. We used MTT assay described by Mosmann [11] with minor modifications. In brief, HepG2 cells were seeded in 96-well culture plates at the density of $2.5 \times 10^{5} \mathrm{cells} / \mathrm{ml} .200 \mu \mathrm{l}$ of suspension were added to each well. After overnight incubation, cells were treated with different concentrations of carvacrol or rosemary oil as mentioned above. After treatment, the medium was removed and cells were incubated with $50 \mu \mathrm{l}$ of MTT dye solution $(1 \mathrm{mg} / \mathrm{ml}$ in PBS) suspended in $100 \mu$ lof complete RPMI medium for $4 \mathrm{~h}$ at $37^{\circ} \mathrm{C}$. The medium was removed and DMSO was added to each well and plates were continuously shaken for $30 \mathrm{~min}$. Photometric evaluation (at $540 \mathrm{~nm}$ excitation and $690 \mathrm{~nm}$ emission wavelengths) was carried out using the $\mathrm{xMark}^{\mathrm{m}}$ Microplate Absorbance Spectrophotometer (Bio-Rad Laboratories, Inc., Hercules, CA, USA). The viability of HepG2 cells was calculated by the following formula: $\mathrm{A}_{\text {treated cells }} / \mathrm{A}_{\text {control cells }} \times 100 \%$.

Conventional and modified single cell gel electrophoresis (SCGE; comet assay). The procedure of SCGE described by Singh et al. [12] and modified by Slamenova et al. [13] was used with minor adjustments. In brief, microscopic 
slides were coated with $1 \%$ NMP agarose in distilled water and dried. The tested HepG2 cells (untreated or treated as mentioned in section Treatment of cells) at a density of 2.5$3 \times 10^{4}$ cells $/ 50 \mu$ of $0.75 \%$ LMP agarose in PBS were placed on pre-coated microscopic slides and covered with a cover slip. After solidification of the gels, the cover slips were removed and slides were placed in a lysis mixture $(2.5 \mathrm{M} \mathrm{NaCl}, 100$ $\mathrm{mM} \mathrm{Na} \mathrm{EDTA}_{2} 10 \mathrm{mM}$ Tris, pH 10, 1\% Triton X-100) for $1 \mathrm{~h}$ at $4^{\circ} \mathrm{C}$. In conventional SCGE, samples were consequently transferred to an electrophoresis solution $(300 \mathrm{mM} \mathrm{NaOH}$, $1 \mathrm{mM} \mathrm{Na}{ }_{2} \mathrm{EDTA}, \mathrm{pH}>13$ ) for $40 \mathrm{~min}$ unwinding at $4^{\circ} \mathrm{C}$ and then subjected to electrophoresis at $25 \mathrm{~V}$ (current adjusted to $0.3 \mathrm{~A}$ ) for $30 \mathrm{~min}$ at $4^{\circ} \mathrm{C}$. Finally, slides were neutralized with $400 \mathrm{mM}$ Tris- $\mathrm{HCl}$ ( $\mathrm{pH}$ 7.5) twice for $10 \mathrm{~min}$ and stained with a fluorescent dye $(\mathrm{EtBr}, 5 \mu \mathrm{g} / \mathrm{ml})$.

For detection of oxidative DNA lesions induced by DMNQ modified comet assay described by Collins et al. [14] was used. After lysis, samples were washed twice in endonuclease buffer (40 mM Hepes, $100 \mathrm{mM} \mathrm{KCl,} 0.5 \mathrm{mM}$ EDTA, pH 8) for $10 \mathrm{~min}$ and incubated for $30 \mathrm{~min}$ with formamidopyrimidineDNA-glycosylase (Fpg) in a moist box at $37^{\circ} \mathrm{C}$. The control slides were incubated with endonuclease buffer containing $0.2 \mathrm{mg} / \mathrm{ml} \mathrm{BSA}$. The final dilution of Fpg was $0.2 \mathrm{U} /$ slide. The following steps of unwinding, electrophoresis, neutralization and DNA staining were identical both in the conventional and modified technique.

For evaluation of DNA damage as \% DNA in the tail at least $100 \mathrm{EtBr}$-stained nucleoids were scored for each slide with a Zeiss fluorescent microscope and automated computerized image analysis Metafer 3.6 system (MetaSystems $\mathrm{GmbH}$, Altlussheim, Germany).

In vitro BER capacity of cell extracts. This method evaluates the ability of an extract prepared from cells of different origin to cleave DNA substrate (mammalian cells) containing specific damage $[15,16,17]$. In our experiments, we used extracts prepared from hepatocytes isolated from control (water/CrEL) and fed (carvacrol/rosemary oil) rats. The strain of experimental rats, their maintenance, protocols for feeding with carvacrol or rosemary oil and isolation of their hepatocytes were thoroughly described in our previous papers $[18,19]$. Oxidative damage of DNA substrate coming from HepG2 cells was induced by DMNQ. For measurement of the BER activity of extracts modified comet assay was used.

Hepatocyte extracts preparation. Extracts from hepatocytes of control and supplemented SD rats were prepared as described Collins et al. [15]. Freshly isolated hepatocytes were washed in $3 \times$ diluted extraction buffer A ( $45 \mathrm{mM}$ Hepes, $400 \mathrm{mM} \mathrm{KCl}, 1 \mathrm{mM}$ EDTA, $0.1 \mathrm{mM}$ dithiothreitol, $10 \%$ glycerol, adjusted to $\mathrm{pH} 7.8$ using $\mathrm{KOH}$ ) and centrifuged at $700 \mathrm{~g}$ for $5 \mathrm{~min}$ at $4^{\circ} \mathrm{C}$. Then, supernatant was removed as much as possible, the pellet was resuspended by vigorously tapping the tube and $100 \mu$ l of buffer A was added for each $1 \times 10^{7}$ cell. Suspension of cells was divided into $50 \mu \mathrm{l}$ aliquots, frozen and stored at $-80^{\circ} \mathrm{C}$.
For quantification of proteins concentration, $50 \mu$ aliquots were thawed, mixed with RadioImmunoPrecipitation Assay lysis buffer (50 mM Tris- $\mathrm{HCl} \mathrm{pH} \mathrm{7.4,} 150 \mathrm{mM} \mathrm{NaCl}, 1 \mathrm{mM}$ $\mathrm{Na}_{2}$ EDTA, $1 \%$ Triton $\mathrm{X}-100$ ) kept for $30 \mathrm{~min}$ at $4^{\circ} \mathrm{C}$ and centrifuged at $14000 \mathrm{~g}$ for $20 \mathrm{~min}$ at $4^{\circ} \mathrm{C}$. The supernatant was collected and proteins concentration was determined by Bradford's method with BSA as a standard and Quick Start ${ }^{\mathrm{TM}}$ Bradford Dye Reagent (Bio-Rad Laboratories Inc., Hercules, CA, USA).

In vitro repair incubation with extracts and Fpg. Hepatocyte extracts were thawed, $12 \mu \mathrm{l}$ of $1 \%$ Triton X-100 in buffer A was added and centrifuged $(14000 \mathrm{~g}, 5 \mathrm{~min}$, $4^{\circ} \mathrm{C}$ ) just before use. Nuclei and cell debris were separated by this centrifugation to pellet. The supernatant was mixed with reaction buffer B (45 mM Hepes, $0.25 \mathrm{mM}$ EDTA, 2\% glycerol, $0.3 \mathrm{mg} / \mathrm{ml} \mathrm{BSA}$, adjusted to $\mathrm{pH} 7.8$ using $\mathrm{KOH}$ ) and kept on ice until use. After lysis, slides with DNA substrate (i.e. HepG2 cells containing oxidative damage) were washed twice for 10 min with reaction buffer B without BSA. Then $40 \mu \mathrm{l}$ of prepared extracts was added to appropriate samples and incubated $\left(30 \mathrm{~min}, 37^{\circ} \mathrm{C}\right)$ in moist boxes. Reaction buffer B with BSA was used as a negative control. As positive control we used Fpg enzyme. The following steps were identical in the conventional and modified procedure as described in section Conventional and modified single cell gel electrophoresis.

DAPI staining. The signs of apoptosis after 24 hour exposure of HepG2 cells to individual concentrations of carvacrol $(300-600 \mu \mathrm{M})$ and rosemary oil $\left(37.5-125 \times 10^{-3} \%\right.$ ) with subsequent 48 hour post-cultivation in fresh medium were analyzed similarly as described Valovicova et al. [20]. Briefly, cells were seeded on Petri dishes at a density of $2 \times 10^{5}$ cells/dish. After treatment, cell cultures were fixed with ice-cold methanol: glacial acetic acid (3:1) for $15 \mathrm{~min}$ at room temperature, washed and air dried till next day. Thus fixed cells were stained with DAPI $(0.2 \mu \mathrm{g} / \mathrm{ml})$ diluted in McIlvaine's buffer $\left(0.2 \mathrm{M} \mathrm{Na}_{2} \mathrm{HPO}_{4} \times 2 \mathrm{H}_{2} \mathrm{O}\right.$, adjusted to $\mathrm{pH} 7$ using citric acid) at room temperature in the dark for $40 \mathrm{~min}$, washed, dried and mounted with glycerol. Cell death (apoptosis and necrosis) was determined using morphological criteria (fragmentation of nuclei) by Oberhammer et al. [21]. Two thousand cells per dish were analyzed using the fluorescence microscope Olympus BX51.

Statistical analysis. The results are presented as means from at least three sets of independent experiments \pm standard deviation (SD). The significance of differences between samples was evaluated by Student's $t$-test. $P$ value of $<0.05$ was considered significant.

\section{Results}

Cytotoxic effect of volatiles on HepG2 cells. Cytotoxicity of plant volatiles - carvacrol and rosemary essential oil - on HepG2 cells was evaluated by trypan blue exclusion as well as by MTT assays. It is evident that both volatiles inhibited cell 

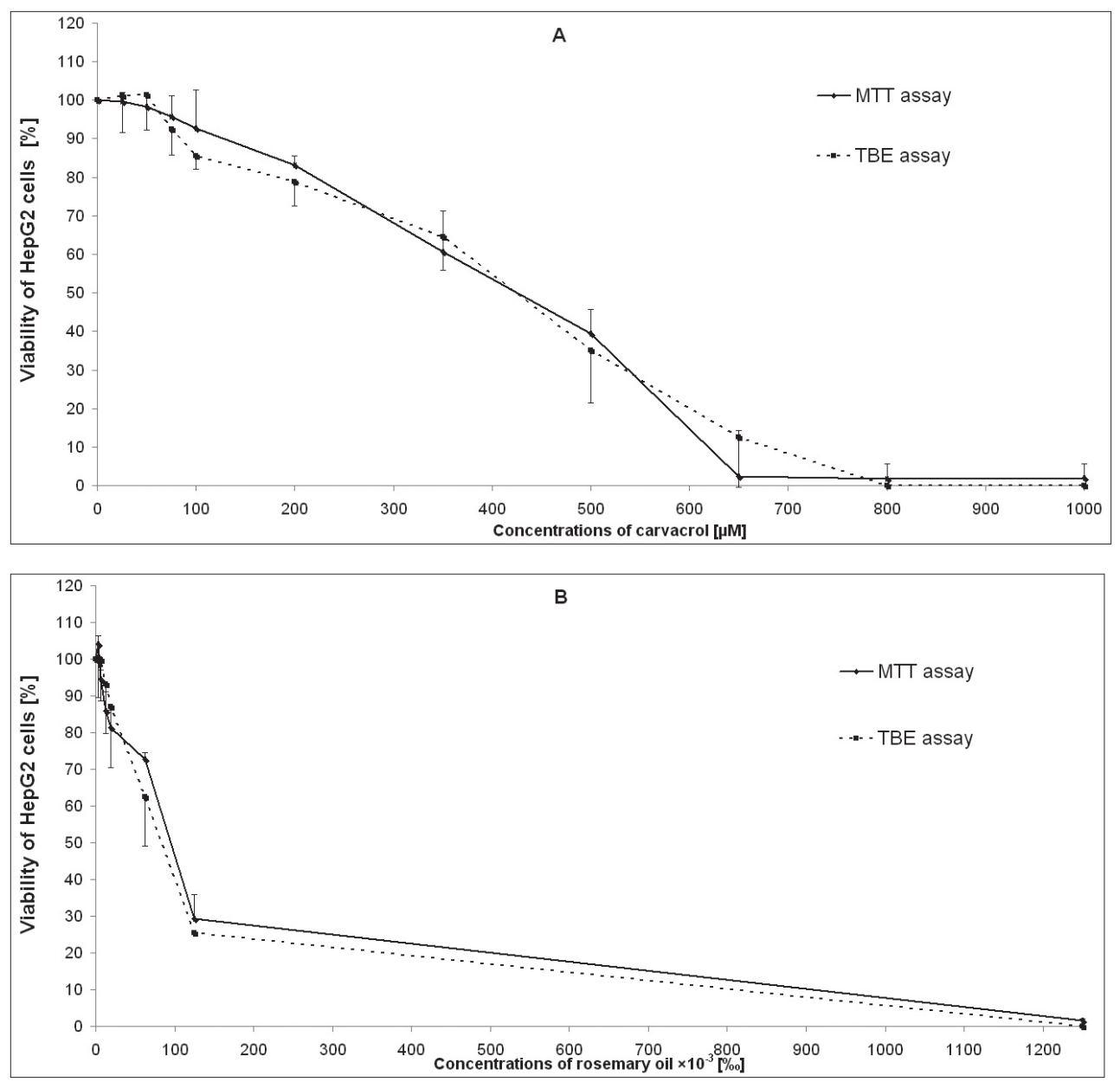

Figure 1. Cytotoxic effects of carvacrol (A) and rosemary oil (B) measured by MTT (black lines) and TBE (dashed lines) assays.

growth and viability gradually with increasing concentrations (Figure 1). 50\% growth inhibitory concentration $\left(\mathrm{IC}_{50}\right)$ for 24 hour treatment with carvacrol was $425 \mu \mathrm{M}$ (Figure 1A). Figure $1 \mathrm{~B}$ shows that $\mathrm{IC}_{50}$ value for 24 hour treatment with rosemary oil was approximately $89 \times 10^{-3} \%$. For further experiments intended to study potential DNA-protective effects of volatiles using comet assay concentrations exhibiting cell viability approximately $80 \%$ were chosen.

DNA-protective effects of volatiles against $\mathrm{H}_{2} \mathrm{O}_{2}$ and DMNQ. To evaluate potential DNA-protective effects of carvacrol and rosemary oil, HepG2 cells were pre-incubated for 24 hours with volatiles before treatment with $\mathrm{H}_{2} \mathrm{O}_{2}$ (Figure 2) or DMNQ (Figure 3). At tested concentrations carvacrol and rosemary oil (except the highest concentration) did not induce either ssDNA breaks or oxidized purines (Fpg-sensitive sites). In the conventional assay, both carvacrol and rosemary oil significantly decreased ssDNA breaks induced by $\mathrm{H}_{2} \mathrm{O}_{2}$ (Figure 2). This reduction was for rosemary oil-pre-treatment dose-dependent. In the assay with DMNQ (modified comet assay), both carvacrol and rosemary oil significantly decreased ssDNA breaks as well as oxidative DNA lesions induced by DMNQ (Figures $3 \mathrm{~A}$ and $3 \mathrm{~B}$ ).

Incision capacity of hepatocyte extracts from volatiles fed animals. For measuring the incision capacity of extracts prepared from hepatocytes of control, carvacrol or rosemary oil fed SD rats, modified comet assay was used. Optimizing the use of hepatocytes extracts in in vitro BER assay was tested in separate experiments (data not shown). On the basis of these experiments we chose a suitable dilution of extract in which concentration of proteins was $0.024 \mathrm{mg} / \mathrm{ml}$. At this dilution, significantly higher activity of extract in comparison to negative control (Figure 4, $50 \mu \mathrm{M}$ DMNQ, extract buffer - white bar; ${ }^{* *} p<0.01$ ) along with significantly lower activity then in positive control (Figure 4 , $50 \mu \mathrm{M}$ DMNQ, Fpg - black bar; $+++p<0.001$ ) was observed.

We prepared a substrate DNA containing oxidative DNA damage (HepG2 cells treated with $50 \mu \mathrm{M}$ DMNQ). Substrates of cells were incubated with extracts prepared from hepatocytes isolated from SD rats to drinking water in which 


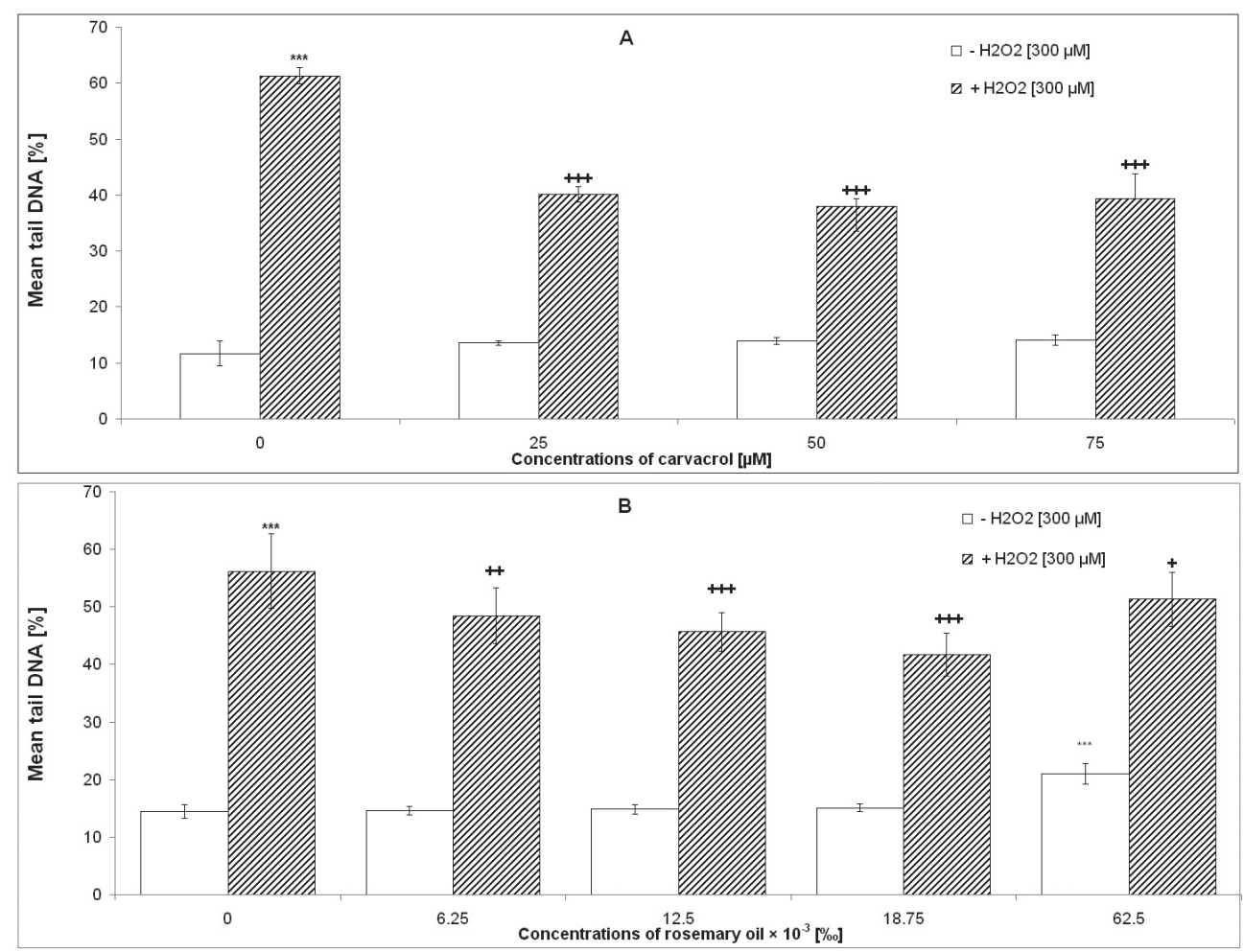

Figure 2. Protective effect of carvacrol (A) and rosemary oil (B) against $\mathrm{H}_{2} \mathrm{O}_{2}$ measured by conventional comet assay. HepG2 cells were pre-incubated for $24 \mathrm{~h}$ with carvacrol or rosemary oil (white columns) before treating with $300 \mu \mathrm{M} \mathrm{H}_{2} \mathrm{O}_{2}$ (striped columns). HepG2 cells treated only with $\mathrm{H}_{2} \mathrm{O}_{2}$ was used as a positive control (striped columns of sample 0); samples incubated only with PBS represent a negative control (white columns of sample 0). ${ }^{* *} p<0.001$ indicate significant difference to negative control; ${ }^{+} p<0.05 ;{ }^{++} p<0.01 ;{ }^{++} p<0.001$ refers to significant difference to positive control.

carvacrol ( 30 or $60 \mathrm{mg} / \mathrm{kg}$ ) or rosemary oil $(0.25$ or $0.5 \%$ ) was added. Figure 4 represents an increased level of DNA damage in substrate cells after treatment with Fpg (positive control) in comparison with substrate incubated only with extract buffer (negative control) $\left.{ }^{* * *} p<0.001\right)$. Control extracts and extracts prepared from hepatocytes isolated from SD rats fed with carvacrol (A) or rosemary oil (B) increased DNA damage in substrate when compared with the negative control ( ${ }^{*} p<0.05$; $\left.{ }^{* *} p<0.01 ;{ }^{* * *} p<0.001\right)$. Simultaneously, extracts from hepatocytes exhibited less DNA damage in substrate compared with positive control $\left({ }^{++} p<0.001\right)$. From the presented results we can conclude that the feeding of carvacrol or rosemary oil to rats did not affect repair activity.

Apoptotic DNA fragmentation induced by volatiles in HepG2 cells. We investigated the ability of carvacrol (Figure $5 \mathrm{~A}$ ) and rosemary essential oil (Figure 5B) to induce apoptotic cell death by the fluorescent microscopic analysis of DNA fragmentation of nuclei. HepG2 cells were treated with volatiles for 24 hours and consequently post-cultivated in the medium for 48 hours. We found out that increasing concentrations of both compounds decreased the rate of cell division and induced nuclear fragmentation and formation of membrane-enclosed fragments-apoptotic bodies typical for apoptosis.

\section{Discussion}

In the past natural products were successfully used to treat a variety of diseases and to maintain health in humans. These compounds play an important part not only in traditional medicine but they are increasingly used in modern medicine. Numerous studies have confirmed that fruit, vegetables or herbs contain compounds that help in the treatment or lower the incidence of certain cancers and cardiovascular or neurodegenerative diseases [22]. In aerobic organism, reactive oxygen species (ROS) are invariably eliminated and generated thereby they play an important role in the development of human diseases. In general, ROS are defined as oxygen-containing chemical species with reactive properties that include free radicals $\left(\mathrm{O}_{2}-/ \mathrm{OH}^{-}\right)$with unpaired electron or non-radical molecules, e.g. hydrogen peroxide. Cells normally produce ROS as by-products of respiration or in the inflammatory processes. Normal cells possess enzymatic and non-enzymatic mechanisms to maintain the balance of ROS production. However, in a state of increased oxidative stress, the balance of oxidants and antioxidants has been disrupted, thereby causing elevated oxidative cellular damage [23, 9]. Many components of plant essential volatiles, for example carvacrol and rosemary 

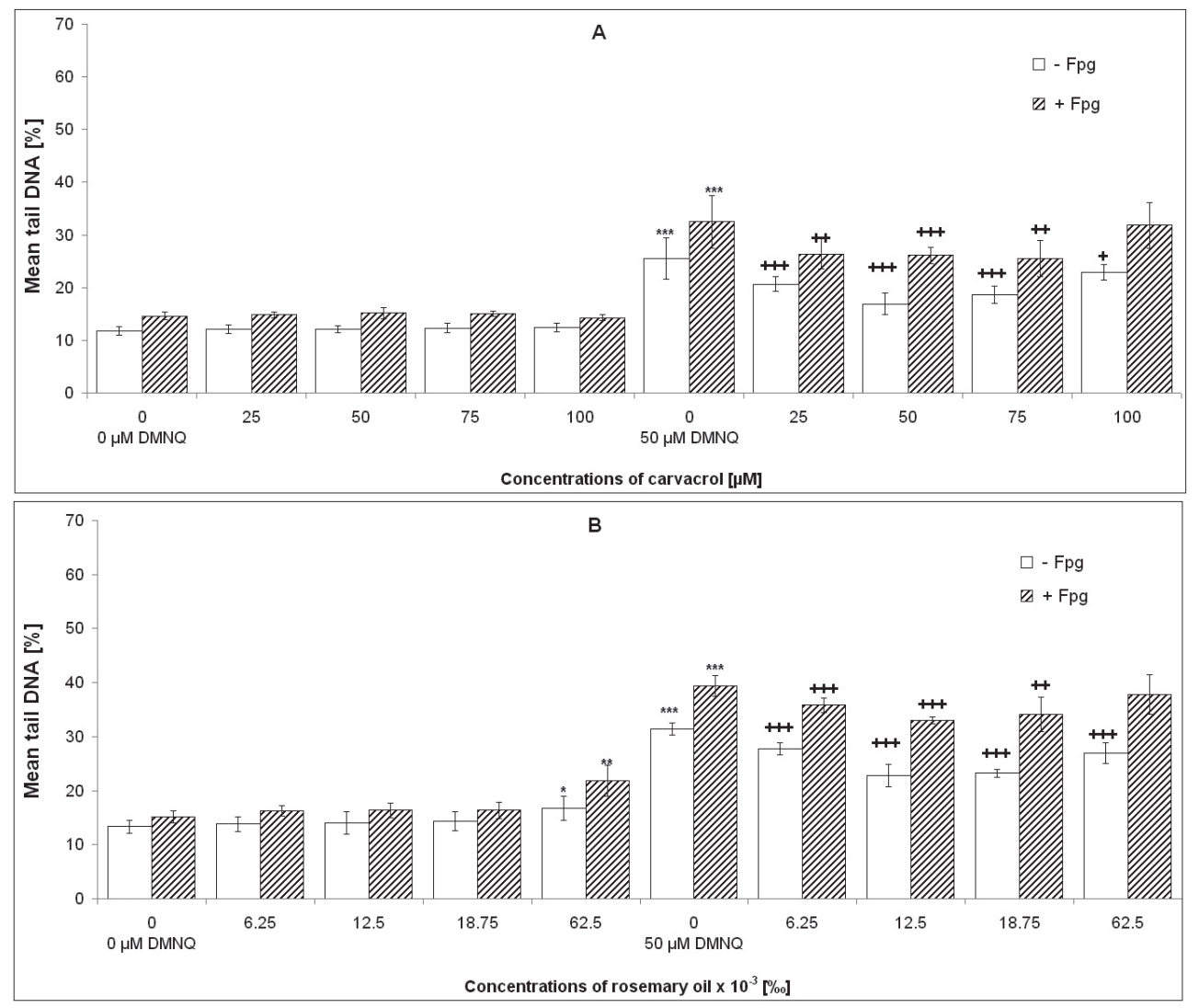

Figure 3. Protective effect of carvacrol (A) and rosemary oil (B) against DMNQ measured by modified comet assay. HepG2 cells were pre-incubated for $24 \mathrm{~h}$ with carvacrol or rosemary oil (left parts) before treating with $50 \mu \mathrm{M}$ DMNQ (right parts). White columns show DNA breaks and alkali-labile sites, striped columns represent additional oxidized DNA bases as Fpg-sensitive sites. Also shown: control cells without DMNQ as negative control (white and striped columns of sample 0 in left parts); control samples with DMNQ as positive control (white and striped columns of sample 0 in right parts). ${ }^{\star} p<0.05 ;{ }^{* *} p<0.01 ;{ }^{* *} p<0.001$ indicate significant difference to negative control; ${ }^{+} p<0.05 ;{ }^{++} p<0.01 ;{ }^{+++} p<0.001$ refers to significant difference to positive control.

essential oil, are the objects of scientific interest for their cytotoxic [24], antioxidant and protective properties [19].

Carvacrol is a component of numerous aromatic plants which has been evaluated for substantial pharmacological properties. It has been proved that carvacrol inhibited the proliferation of two human cervical cancer cell lines HeLa and $\mathrm{SiHa}$ after 48 hours treatment at clinically acceptable concentrations $\left(\mathrm{IC}_{50} \leq 50 \mu \mathrm{g} / \mathrm{ml}\right)$ [25]. Authors also confirmed that carvacrol could have a potential therapeutic utilization in treating cancer. Koparal and Zeytinoglu [26] tested the influence of various concentrations of carvacrol on human non-small cell lung cancer cell line A549 for $24 \mathrm{~h}$ and demonstrated its significant concentration-dependent cytotoxic and apoptotic effect. Rosmarinus officinalis is a popular herb used in traditional medicine. Aherne et al. [27] treated human colon carcinoma Caco-2 cells with increasing concentrations of rosemary extract for 24 hours and found out that the viability of cells was significantly reduced after addition of rosemary $(\geq 30 \mu \mathrm{g} / \mathrm{ml})$. Chinese hamster lung V79 fibroblasts were incubated with rosemary extract for 24 hours and cytotoxicity of this extract was reported at concentrations of $>15 \mu \mathrm{g} / \mathrm{ml}$ [28].

We investigated the cytotoxic effect of two volatiles, carvacrol and rosemary essential oil, on human hepatoma cell line HepG2 by MTT and TBE assays. Our results showed that HepG2 cells were more sensitive to both tested compounds in comparison to human fibroblastoid cell line B-HNF-1 in which $\mathrm{IC}_{50}=680 \mu \mathrm{M}$ (carvacrol) and $108 \times 10^{-3} \%$ o (rosemary oil) were detected (data not shown). These observations are consistent with results of Yin et al. [2] which indicated that human foetal normal liver LO2 cells were more resistant to the cytotoxic effect of carvacrol, without significant effect on cell viability, while HepG2 cells showed $\mathrm{IC}_{50}=0.4 \mathrm{mM}$ after $24 \mathrm{~h}$ treatment.

Experiments have proved that carvacrol itself causes DNA-damage at the higher concentration of $0.1 \mathrm{mM}$ in human lymphocytes but on the other hand it seemed to protect lymphocytes from genotoxic effects of 2 -amino3-methylimidazo[4,5-f]-quinoline (IQ) and mitomycin 

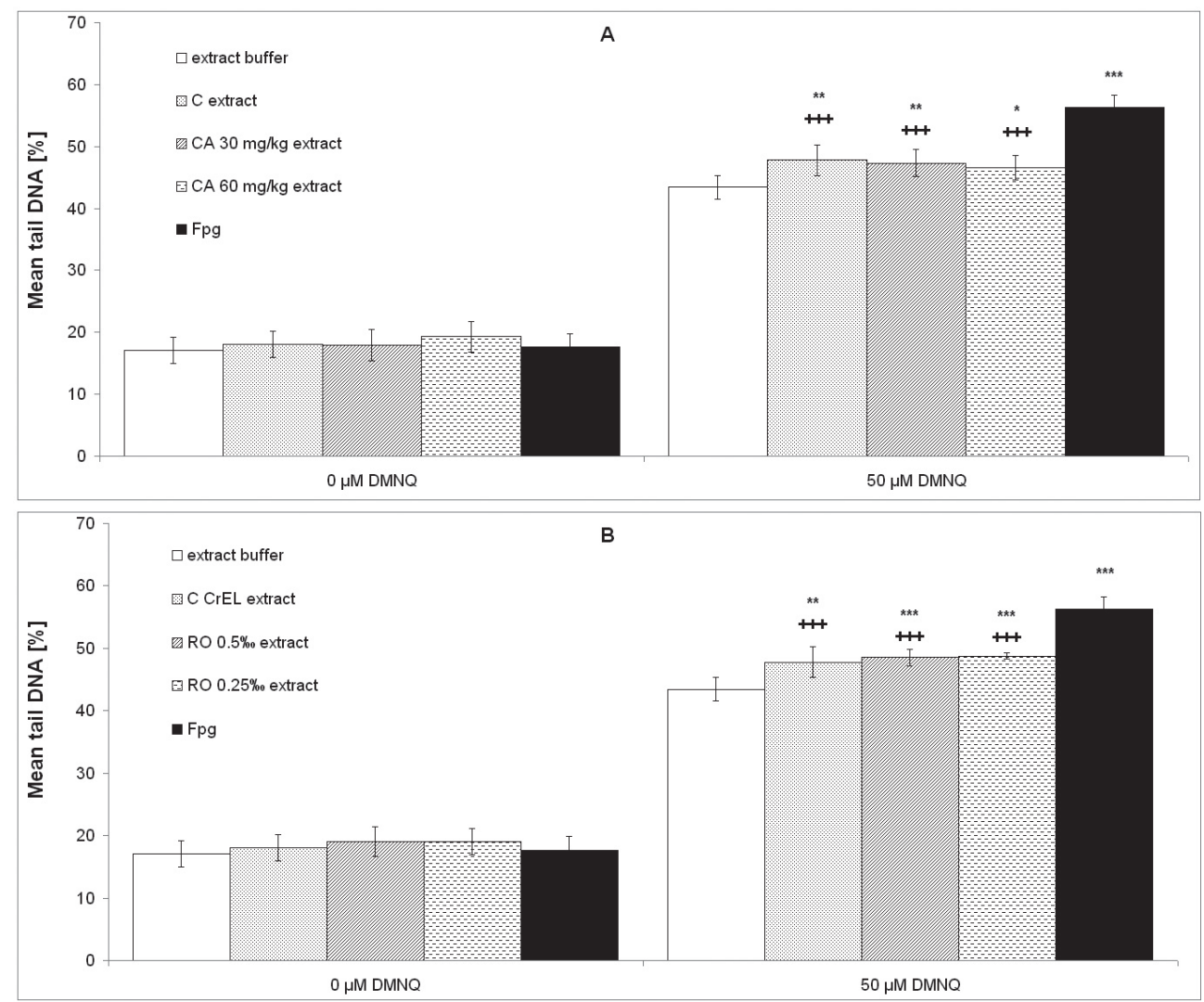

Figure 4. In vitro BER assay measured by modified comet assay. Control extracts (water/CrEL; light gray bars) and extracts prepared from hepatocytes isolated from SD rats fed by carvacrol (A; $30 \mathrm{mg} / \mathrm{kg}$ - dark gray bars or $60 \mathrm{mg} / \mathrm{kg}$ - dashed bars) or rosemary oil (B; 0.25\% - dashed bars or $0.5 \%$ - dark gray bars) were incubated for $30 \mathrm{~min}$ with substrate containing oxidative DNA damage induced by $50 \mu \mathrm{M}$ DMNQ. Fpg enzyme was used as positive control (black bars) and extract buffer (white bars) as negative control. ${ }^{*} p<0.05$; ${ }^{* *} p<0.01$; ${ }^{* *} p<0.001$ indicate significant difference to negative control and $+++p<0.001$ refers to significant difference to positive control.

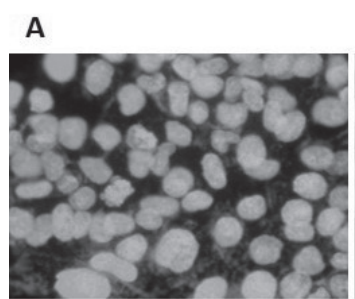

1

B

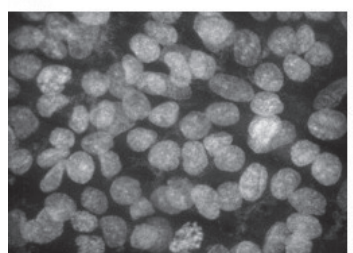

1

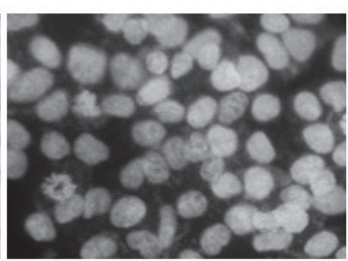

2

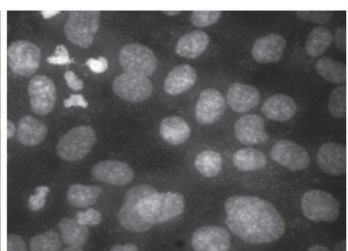

2

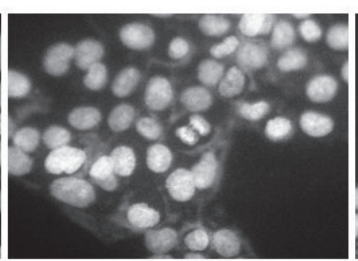

3

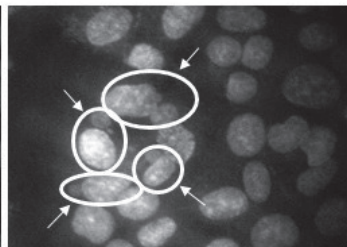

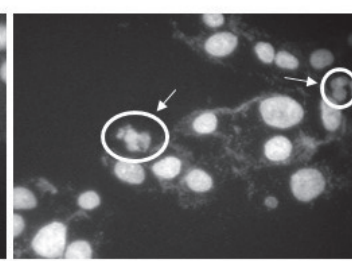

4

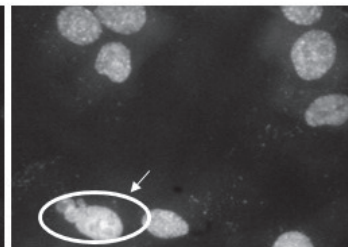

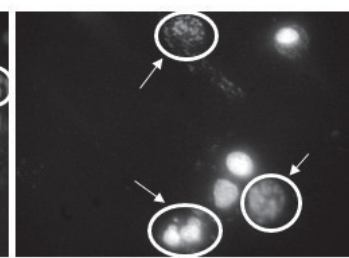

5

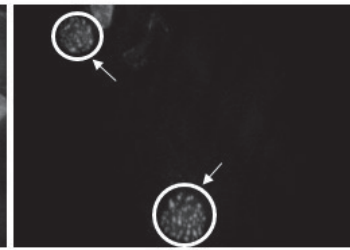

Figure 5. DAPI staining of apoptotic morphological changes in nuclei of HepG2 cells treated for $24 \mathrm{~h}$ with different concentrations of carvacrol (A) or rosemary oil (B) and following $48 \mathrm{~h}$ post-cultivation. For carvacrol (A), the numbers represent: $1=$ untreated cells; $2=300 \mu \mathrm{M} ; 3=400 \mu \mathrm{M} ; 4=500 \mu \mathrm{M}$; $5=600 \mu \mathrm{M}$. For rosemary oil, the numbers represent: $1=$ untreated cells; $2=37.5 \times 10^{-3} \%$; $3=62.5 \times 10^{-3} \% 0 ; 4=93.75 \times 10^{-3} \% 0 ; 5=125 \times 10^{-3} \%$. 
C (MMC) at non-toxic concentrations below $0.05 \mathrm{mM}$ [29]. Aydin et al. [30] also reported that in human lymphocytes low concentrations of carvacrol protected DNA from oxidative damage mediated by hydroxyl radicals from hydrogen peroxide $\left(\mathrm{H}_{2} \mathrm{O}_{2}\right)$, while the high concentrations increased DNA damage. Numerous studies demonstrated that carvacrol was able to decrease level of single-strand breaks or oxidative DNA damage in different cells lines: in $\mathrm{H}_{2} \mathrm{O}_{2}$-influenced human HepG2 and Caco-2 cells [31], in $\mathrm{H}_{2} \mathrm{O}_{2}$-influenced human leukemic K562 cells [32] and in HepG2 cells damaged by tert-butyl hydroperoxide ( $t$-BHP) [33]. Jayakumar et al. [34] determined chemopreventive effect of carvacrol against diethylnitrosamine (DEN)-induced hepatocellular carcinoma in rats as well as undoubtedly induced apoptosis in tumor cells. Canbek et al. [35] investigated the action of carvacrol against liver injury caused by ischemia and reperfusion in rats and showed its protective effect on the functional defects of hepatocytes. It was proved that carvacrol significantly reduced DNA damage induced by different concentrations of $\mathrm{H}_{2} \mathrm{O}_{2}$ in hepatocytes and testicular cells isolated from carvacrol fed experimental rats [18].

Zegura et al. [36] demonstrated that two rosemary extracts exhibited similar preventive action against DNA damage induced by $t$-BHP, benzo[a]pyrene or 2-amino-1-methyl-6phenylimidazol[ $[4,5-b]$ pyridine. From the previously published results it is clear that rosemary oil given to rats for 14 days significantly reduced DNA damage caused by oxidizing agents $\mathrm{H}_{2} \mathrm{O}_{2}$, DMNQ and visible light-excited methylene blue in freshly isolated hepatocytes [19].

Brevik et al. [37] investigated the influence of nutritional factors on BER in humans. The effects of fruit and antioxidantrich plant products on BER were tested in lymphocytes of male volunteers for 8 weeks. This epidemiological study showed a reduced level of DNA strand breaks after the consumption of natural compounds. The authors concluded that DNA repair is related to diet.

Several authors described different effects and properties of Rosmarinus officinalis extracts that are usable in the food industry but only a few of them focused on the protective and genotoxic potential of essential oil isolated from this plant. In this study we therefore examined the effects of carvacrol and rosemary oil on HepG2 cells and proved DNA-protective activities of both volatiles against DNA damage induced by $\mathrm{H}_{2} \mathrm{O}_{2}$ and DMNQ.

DNA repair activity is considered to be an important biomarker in cancer risk. For evaluation of base excision repair (BER) pathways we used a repair activity technique which is based on the incubation of cell extracts with DNA substrate (HepG2 cells) containing specific damage, e.g. oxidized purines as 8 -oxoG. The level of these lesions is measured by a modified version of single cell gel electrophoresis (comet assay) [38]. Ramos et al. [39] noted that ursolic acid and luteolin had protective effects on DNA damage induced by $\mathrm{H}_{2} \mathrm{O}_{2}$ and photosensitizer Ro 19-8022 plus visible light in Caco-2 cells, but only ursolic acid enhanced the base excision repair activ- ity of these cells. Borneol, a component of many essential oils, was also tested for its DNA-protective effects and influence on BER capacity of extracts prepared from hepatocytes of rats fed with borneol. The results confirmed DNA-protective activity of borneol against exogenous oxidative DNA damage and no effect of borneol on incision activity of hepatocytes [16]. These observations are consistent with our findings obtained measuring the in vitro BER activity of extracts prepared from hepatocytes isolated from carvacrol or rosemary oil fed rats and incubated with HepG2 cells damaged by DMNQ. Similar results were observed using extracts prepared from testicular cells of carvacrol-fed SD rats (data not shown). We reported here that incision activity of primary rat hepatocytes was not influenced by feeding SD rats with carvacrol or rosemary oil.

Cells can respond to foreign substances by either activation or suppression of cell death mechanisms that may be considered to be either protective (as in carcinogenesis) or damaging (in neurodegeneration) to the organism [40]. The essential oil from Origanum onites L. and carvacrol were investigated for their apoptotic effect in HepG2 cells after 48 hour incubation using acridine orange/ethidium bromide staining. Both tested substances demonstrated characteristic apoptotic morphology such as chromatin condensation or cytoplasmic blebbing [24]. Arunasree et al. [41] evaluated the apoptotic effect of carvacrol in human metastatic breast cancer MDA-MB231 cells by different methods like Annexin $\mathrm{V}$ assay or cell cycle analysis. Results showed that carvacrol clearly induced apoptosis which was reflected by the release of cytochrome c from mitochondria, caspase activation and cleavage of PARP. Cheng et al. [42] explored the apoptotic effect of rosmanol, one of the components of Rosmarinus officinalis, in human colorectal adenocarcinoma COLO 205 cells. Their study proved that rosmanol induced apoptosis and involved the regulation of the mitochondrial apoptotic pathway as well as the death receptor pathway. Ursolic acid, another component of rosemary, activated an apoptotic pathway as a response to stress in human bladder cancer T24 cells [43]. These findings are in agreement with our results which demonstrated apoptotic morphological changes of nuclei (DAPI staining). We confirmed results of DAPI staining by DNA internucleosomal fragmentation (electrophoresis) in HepG2 cells treated with carvacrol and rosemary oil (data not shown).

We can conclude that carvacrol and rosemary oil had no genotoxic effect on HepG2 cells. On the contrary, both volatiles showed a DNA-protective effect against oxidative DNA damage induced by $\mathrm{H}_{2} \mathrm{O}_{2}$ and DMNQ. The addition of carvacrol or rosemary oil to the drinking water of SD rats had however no effect on the repair capacity of their hepatocytes. We also noted that these natural compounds can trigger apoptotic cell death pathways in HepG2 cells. Thus, the current work indicates that the volatiles studied could be applicable as beneficial nutrients in food and at the same time they could function as potential antitumor molecules against cancer cells. 
Acknowledgements: This study was supported by the Scientific Grant Agency of the Ministry of Education of Slovak Republic and the Academy of Sciences (VEGA) grants 2/0072/09, 2/0012/12, by the Slovak Research and Development Agency grant APVV-0339-10 and by the project implementation: TRANSMED, ITMS: 26240120008 and ITMS: 26240220071 supported by the Research \& Development Operational Programme funded by the ERDF. The authors thank Mrs. Alzbeta Vokalikova and Mrs. Anna Moravkova for excellent technical assistance.

\section{References}

[1] BAKKALI F, AVERBECK S, AVERBECK D, IDAOMAR $M$ Biological effects of essential oils-A review. Food and Chemical Toxicology 2008; 46: 446-475. http://dx.doi. org/10.1016/j.fct.2007.09.106

[2] YIN Q, YAN F, ZU X-Y, WU Y, WU X et al. Anti-proliferative and pro-apoptotic effect of carvacrol on human hepatocellular carcinoma cell line HepG-2. Cytotechnology 2012; 64: 43-51. http://dx.doi.org/10.1007/s10616-011-9389-y

[3] BASER KHC Biological and Pharmacological Activities of Carvacrol and Carvacrol Bearing Essential Oils. Current Pharmaceutical Design 2008; 14: 3106-3120. http://dx.doi. org/10.2174/138161208786404227

[4] OJEDA-SANA AM, VAN BAREN CM, ELECHOSA MA, JUAREZ MA, MORENO S New insights into antibacterial and antioxidant activities of rosemary essentials oils and their main components. Food Control 2013; 31: 189-195. http://dx.doi. org/10.1016/j.foodcont.2012.09.022

[5] JIANG Y, WU N, FU YJ, WANG W, LUO M et al. Chemical composition and antimicrobial activity of the essential oil of Rosemary. Environmental Toxicology and Pharmacology 2011; 32: 63-68. http://dx.doi.org/10.1016/ j.etap.2011.03.011

[6] MELLOFILHO AC, MENEGINI R In vivo formation of singlestrand breaks in DNA by hydrogen peroxide is mediated by the Haber-Weiss reaction. Biochimica et Biophysica Acta 1984; 781: 56-63. http://dx.doi.org/10.1016/0167-4781(84)90123-4

[7] TAPPER MA, SHEEDY BR, HAMMERMEISTER DE, SCHMIEDER PK Depletion of cellular protein thiols as an indicator of arylation in isolated trout hepatocytes exposed to 1,4-benzoquinone. Toxicological Sciences 2000; 55: 327-334. http://dx.doi.org/10.1093/toxsci/55.2.327

[8] KAPPUS H, SIES H Toxic drug effects associated with oxygen metabolism: redox cycling and lipid peroxidation. Experientia 1981; 37: 1233-1241. http://dx.doi.org/10.1007/BF01948335

[9] DAVID SS, O'SHEA VL, KUNDU S Base Excision Repair of Oxidative DNA Damage. Nature 2007; 447: 941-950. http:// dx.doi.org/10.1038/nature05978

[10] SUNG JS, DEMPLE B Roles of base excision repair subpathways in correcting oxidized abasic sites in DNA. Febs Journal 2006; 273: 1620-1629. http://dx.doi.org/10.1111/j.17424658.2006.05192.x

[11] MOSMANN T Rapid colorimetric assay for cellular growth and survival: application to proliferation and cytotoxicity assays. Journal of Immunological Methods 1983; 65: 55-63. http://dx.doi.org/10.1016/0022-1759(83)90303-4
[12] SINGH NP, MCCOY MT, TICE RR, SCHNEIDER EL A simple technique for quantitation of low levels of DNA damage in individual cells. Experimental Cell Research 1988; 175: 184-191. http://dx.doi.org/10.1016/00144827(88)90265-0

[13] Slamenova D, GABElOVA A, RUZEKOVA L, CHALUPA I, HORVATHOVA E et al. Detection of MNNGinduced DNA lesions in mammalian cells: Validation of comet assay against DNA unwinding technique, alkaline elution of DNA and chromosomal aberrations. Mutation Research 1997; 383: 243-252. http://dx.doi.org/10.1016/ S0921-8777(97)00007-4

[14] COLLINS AR, DUTHIE SJ, DOBSON VL Direct enzymatic detection of endogenous oxidative base damage in human lymphocyte DNA. Carcinogenesis 1993; 14: 1733-1735. http://dx.doi.org/10.1093/carcin/14.9.1733

[15] COLLINS AR, DUSINSKA M, HORVATHOVA E, MUNRO E, SAVIO $M$ et al. Inter-individual differences in repair of DNA base oxidation, measured in vitro with comet assay. Mutagenesis 2001; 16: 297-301. http://dx.doi.org/10.1093/ mutage/16.4.297

[16] HORVATHOVA E, KOZICS K, SRANCIKOVA A, HUNAKOVA L, GALOVA E et al. Borneol administration protects primary rat hepatocytes against exogenous oxidative DNA damage. Mutagenesis 2012; 27: 581-588. http://dx.doi. org/10.1093/mutage/ges023

[17] LANGIE SAS, CAMERON KM, WALDRON KJ, FLETCHER KPR, VON ZGLINICKI T et al. Measuring DNA repair incision activity of mouse tissue extracts towards singlet oxygen-induced DNA damage: a comet-based in vitro repair assay. Mutagenesis 2011; 26: 461-471. http://dx.doi. org/10.1093/mutage/ger005

[18] SLAMENOVA D, HORVATHOVA E, MARSALKOVA L, WSOLOVA L Carvacrol given to rats in drinking water reduces the level of DNA lesions induced in freshly isolated hepatocytes and testicular cells by $\mathrm{H} 2 \mathrm{O} 2$. Neoplasma 2008; 55: 394-399.

[19] HORVATHOVA E, SLAMENOVA D, NAVAROVA J Administration of rosemary essential oil enhances resistance of rat hepatocytes against DNA-damaging oxidative agents. Food Chemistry 2010; 123: 151-156. http://dx.doi.org/10.1016/ j.foodchem.2010.04.022

[20] VALOVICOVA Z, MARVANOVA S, MESZAROSOVA M, SRANCIKOVA A, TRILECOVA L et al. Differences in DNA damage and repair produced by systemic, hepatocarcinogenic and sarcomagenic dibenzocarbazole derivatives in a model of rat liver progenitor cells. Mutation Research 2009; 665: 51-60. http://dx.doi.org/10.1016/j.mrfmmm.2009.02.014

[21] OBERHAMMER FA, PAVELKA M, SHARMA S, TIEFENBACHER R, PURCHIO AF, et al. Induction of apoptosis in cultured hepatocytes and in regressing liver by transforming growth factor beta 1. Proceedings of the National Academy of Science of the U.S.A. 1992; 89: 5408-5412.

[22] OBRENOVICH ME, NAIR NG, BEYAZ A, ALIEV G, REDDY VP The role of polyphenolic antioxidants in health, disease, and aging. Rejuvenation Research 2010; 13: 631-643. http:// dx.doi.org/10.1089/rej.2010.1043 
[23] PELICANO H, CARNEY D, HUANG P ROS stress in cancer cells and therapeutic implications. Drug Resistance Updates 2004; 7: 97-110. http://dx.doi.org/10.1016/ j.drup.2004.01.004

[24] SIVAS H, TOMSUK O Antiproliferative and apoptotic effects of the essential oil of Origanum onites and carvacrol on Hep-G2 cells. Anadolu University Journal of Science and Technology-C 2011; 1: 171-180.

[25] MEHDI SJ, AHMAD A, IRSHAD M, MANZOOR N, RIZVI MMA Cytotoxic effect of carvacrol on human cervical cancer cells. Biology and Medicine 2011; 3: 307-312.

[26] KOPARAL AT, ZEYTINOGLU M Effects of carvacrol on a human non-small cell lung cancer (NSCLC) cell line, A549. Cytotechnology 2003; 43: 149-154. http://dx.doi.org/10.1023/ B:CYTO.0000039917.60348.45

[27] AHERNE SA, KERRY JP, O'BRIEN NM Effects of plant extracts on antioxidant status and oxidant-induced stress in Caco-2 cells. British Journal of Nutrition 2007; 97: 321-328. http://dx.doi.org/10.1017/S0007114507250469

[28] SLAMENOVA D, KUBOSKOVA K, HORVATHOVA E, ROBICHOVA S Rosemary-stimulated reduction of DNA strand breaks and FPG-sensitive sites in mammalian cells treated with $\mathrm{H} 2 \mathrm{O} 2$ or visible light-excited Methylene Blue. Cancer Letters 2002; 177: 145-153. http://dx.doi.org/10.1016/S03043835(01)00784-4

[29] AYDIN S, BASARAN AA, BASARAN N The effects of thyme volatiles on the induction of DNA damage by the heterocyclic amine IQ and mitomycin C. Mutation Research 2005b; 581: 43-53. http://dx.doi.org/10.1016/ j.mrgentox.2004.10.017

[30] AYDIN S, BASARAN AA, BASARAN N Modulating effects of thyme and its major ingredients on oxidative DNA damage in human lymphocytes. Journal of Agricultural and Food Chemistry 2005a; 53: 1299-1305. http://dx.doi.org/10.1021/ jf0402375

[31] SLAMENOVA D, HORVATHOVA E, SRAMKOVA M, MARSALKOVA L DNA-protective effects of two components of essential plant oils carvacrol and thymol on mammalian cells cultured in vitro. Neoplasma 2007; 54 : 108-112.

[32] HORVATHOVA E, TURCANIOVA V, SLAMENOVA D Comparative study of DNA-damaging and DNA-protective effects of selected components of essential plant oils in human leukemic cells K562. Neoplasma 2007; 54: 478-483.

[33] SLAMENOVA D, KOZICS K, HUNAKOVA L, MELUSOVA $\mathrm{M}$, NAVAROVA J et al. Comparison of biological processes induced in HepG2 cells by tert-butyl hydroperoxide (t-BHP) and hydroperoxide (H2O2): The influence of carvacrol. Mutation Research 2013; 757: 15-22. http://dx.doi. org/10.1016/j.mrgentox.2013.03.014
[34] JAYAKUMAR S, MADANKUMAR A, ASOKKUMAR S, RAGHUNANDHAKUMAR S, GOKULA DHAS K et al. Potential preventive effect of carvacrol against diethylnitrosamine-induced hepatocellular carcinoma in rats. Molecular and Cellular Biochemistry 2012; 360: 51-60. http://dx.doi. org/10.1007/s11010-011-1043-7

[35] CANBEK, M Effects of carvacrol on defects of ischemiareperfusion in the rat liver. Phytomedicine 2008; 15: 447-452. http://dx.doi.org/10.1016/j.phymed.2007.11.022

[36] ZEGURA B, DOBNIK D, NIDERL MH, FILIPIC M Antioxidant and antigenotoxic effects of rosemary (Rosmarinus officinalis L.) extracts in Salmonella typhimurium TA98 and HepG2 cells. Environmental Toxicology and Pharmacology 2011; 32: 296-305. http://dx.doi.org/10.1016/ j.etap.2011.06.002

[37] BREVIK A, KARLSEN A, AZQUETA A, ESTABAN AT, BLOMHOFF R et al. Both base excision repair and nucleotide excision repair in humans are influenced by nutritional factors. Cell Biochemistry and Function 2011; 29: 36-42. http://dx.doi. org/10.1002/cbf.1715

[38] AZQUETA A, LANGIE SA, SLYSKOVA J, COLLINS AR Measurement of DNA base and nucleotide excision repair activities in mammalian cells and tissues using the comet assay-A methodological overview. DNA repair 2013; 12: 1007-1010. http://dx.doi.org/10.1016/j.dnarep.2013.07.011

[39] RAMOS AA, PEREIRA-WILSON C, COLLINS AR Protective effects of ursolic acid and luteolin against oxidative DNA damage include enhancement of DNA repair in Caco-2 cells. Mutation Research 2010; 692: 6-11. http://dx.doi.org/10.1016/ j.mrfmmm.2010.07.004

[40] ORRENIUS S, NICOTERA P, ZHIVOTOVSKY B Cell death mechanisms and their implications in toxicology. Toxicological Sciences 2011; 119: 3-19. http://dx.doi.org/10.1093/toxsci/ kfq268

[41] ARUNASREE KM Anti-proliferative effects of carvacrol on a human metastatic breast cancer cell line, MDA-MB 231. Phytomedicine 2010; 17: 581-588. http://dx.doi.org/10.1016/ j.phymed.2009.12.008

[42] CHENG AC, LEE MF, TSAI ML, LAI CS, LEE JH et al. Rosmanol potently induces apoptosis through both the mitochondrial apoptotic pathway and death receptor pathway in human colon adenocarcinoma COLO 205 cells. Food and Chemical Toxicology 2011; 49: 485-493. http://dx.doi. org/10.1016/j.fct.2010.11.030

[43] ZHENG QY, LI PP, JIN FS, YAO C, ZHANG GH et al. Ursolic acid induces ER stress response to activate ASK1-JNK signaling and induce apoptosis in human bladder cancer T24 cells. Cellular Signaling 2013; 25: 206-213. http://dx.doi. org/10.1016/j.cellsig.2012.09.012 